Vol. 2, No. 1, 2020

https://doi.org/10.23939/jtbp2020.01.009

Volodymyr Snitynskyi ${ }^{1}$, Petro Khirivskyi ${ }^{1}$, Ihor Hnativ ${ }^{1}$, Roman Hnativ ${ }^{2}$

\title{
LANDSLIDES AND EROSION PHENOMENA IN THE FOOTHILLS OF THE CARPATHIAN REGION RIVERS
}

\author{
${ }^{1}$ Lviv National Agrarian University, Dubliany \\ gnativ13@gmail.com \\ ${ }^{2}$ Lviv Polytechnic National University, Lviv \\ gnativ.roman.m@gmail.com
}

(C) Snitynskyi V., Khirivskyi P., Hnativ I., Hnativ R., 2020

The diversity of landscape conditions in the territory of Ukraine is caused by the peculiarities of the geomorphological structure, zonal climatic, hydrogeological and seismic factors, which generally determines the area of distribution of exogenous geological processes (EGP). Most of these processes, namely landslides, karst formations, flooding and erosion of territories, mudflows are activated under natural conditions.

The need to assess the engineering and geological status of areas with intensive development of hazardous hydrogeological processes and the impact of technogenic factors that determine the degree of change and spread of processes, are crucial for the safe development of industry and agriculture. Flood protection of settlements, territories and objects from flooding is an actual problem. Modern methods of flood protection on the rivers of the Ukrainian Carpathians are the regulation of river beds by means of hydrotechnical regulation structures.

The purpose of the conducted researches is to analyze the factors influencing landslides and erosion phenomena in the foothills of the Ukrainian Carpathians and to choose the optimal flood protection of inhabited territories from destruction. In accordance with the requirements of the international monitoring of the environment of the observation network, the points of information gathering and processing need considerable improvement. Restoration of the system of constant monitoring of landslides, floods and washing of the banks and engineering structures on the rivers is essential in the places of their intensive development in dangerous areas.

Obtaining reliable data on the place of formation, factors of activation and development of dangerous exogenous processes can significantly influence the decision making to prevent and eliminate the negative consequences of activation of these processes.

Keywords: exogenous geological processes, protection of territories, floods, flooding, erosion of territories.

\section{Formulation of the problem}

Flood protection and erosion are a major problem for our country. The negative consequences of flooding during periods of floods and spring snowmelt are observed in $27 \%$ of the territory of Ukraine. The greatest damage from flooding is the mountain and foothills of the Ukrainian Carpathians, Polesie, the Danube and Dnieper territories. $17 \%$ of the territory of Ukraine is exposed to flooding processes. Recently, landslides have intensified in $50 \%$ of the developed areas of the slopes, and in $70 \%$ of the mountain catchments of the Ivano-Frankivsk and Transcarpathian regions there are mudslides during heavy rainfall.

In the conditions of insufficient modern financing of flood control measures, only local flood protection of individual settlements and territories has been erected, which does not guarantee reliable protection in dangerous areas of rivers (Khlapuk, 2015). 


\section{Relevance of research}

The need to assess the engineering and geological condition of territories with the intensive development of dangerous hydrogeological processes and the influence of technogenic factors that determine the degree of change and distribution of processes are essential for the safe development of industry and agriculture. Unbalanced and haphazard economic activity has led to negative preconditions for the rapid development of exogenous geological processes (EGP), especially in the foothills of the Carpathian region (Information Yearbook, 2018).

Flood protection of settlements, territories and objects from flooding is an urgent problem. It is necessary to introduce a complex regulation of river beds, taking into account the development of river processes and forecasting its possible changes due to the influence of hydraulic and engineering structures. Modern methods of flood protection on the rivers of the Ukrainian Carpathians are the regulation of river beds by means of hydraulic engineering structures (Khlapuk, 2013).

\section{Formulation of the purpose and objectives of the article}

The aim of the research is to analyze the factors influencing landslides and erosion phenomena in the foothills of the Ukrainian Carpathians and the choice of optimal flood protection of inhabited territories.

\section{Analysis of recent research and publications}

The diversity of landscape conditions in the territory of Ukraine is caused by the peculiarities of the geomorphological structure, zonally climatic, hydrogeological and seismic factors, which generally determines the areas of distribution of EGP. Most of these processes, namely landslides, karst formations, flooding and erosion of territories, mudflows are activated under natural conditions. They are caused by abnormal changes in natural phenomena, hydrological and hydrogeological conditions, but their intensity increases significantly under the influence of technogenic factors. However, the processes of subsidence of the earth's surface over mining, the increase of groundwater levels due to technogenic loading, have arisen in conditions of intensive development of the territory and lead to significant changes in the environment. Significantly increases the threat at the locations of potentially dangerous objects.. These are mining and processing enterprises, reclamation systems, road and railways, oil and gas pipelines, etc. (Klimchuk, 2008).

Landslides are the most common and dangerous, especially in urban areas. The development of this process within Ukraine has regional differences. Regularities of the landslide process manifestation depend on hydrogeological, geomorphological and other natural conditions. However, the formation and activation of landslides are affected by atmospheric precipitation, water levels and flows in surface watercourses, erosion action of surface waters, groundwater feeding and drainage conditions, and seismic processes (Kolot, 1988).

Given the complexity of the prognosis for the development of landslides and their unpredictability over time. They, as a separate type of EGP, are a potential factor for emergencies in Ukraine. Modern activation of landslides is most often caused by technogenic and, to a lesser extent, natural factors.

The activation of landslides is facilitated by the destruction of the upper soil zone, which is caused by deforestation and plowing of land on the slopes, the location of engineering objects on or near the slopes, which leads to an imbalance of the slope areas.

\section{Presenting main material}

The development of landslides has its own peculiarities depending on their location within geological structures, characterized by morphostructural, structural-geological, landscape-climatic, morphometric, hydrogeological features of the territory, as well as seismic and neotectonics. 
In the territory of Ukraine there are 9 regions: 5 in the southwestern part of the Eastern European Platform and 4 - within the Alpine folding (Fig. 1).

The region of the Volyn-Podilsky Plate and the Halych-Volyn Basin covers the territories of Volyn, Rivne, Ternopil and part of the territories of Lviv, Ivano-Frankivsk, Chernivtsi and Khmelnitsky regions. Landslides are unevenly spread across the region. The most intense process is recorded in the southeastern part of the region, on the right bank of the Dniester River.

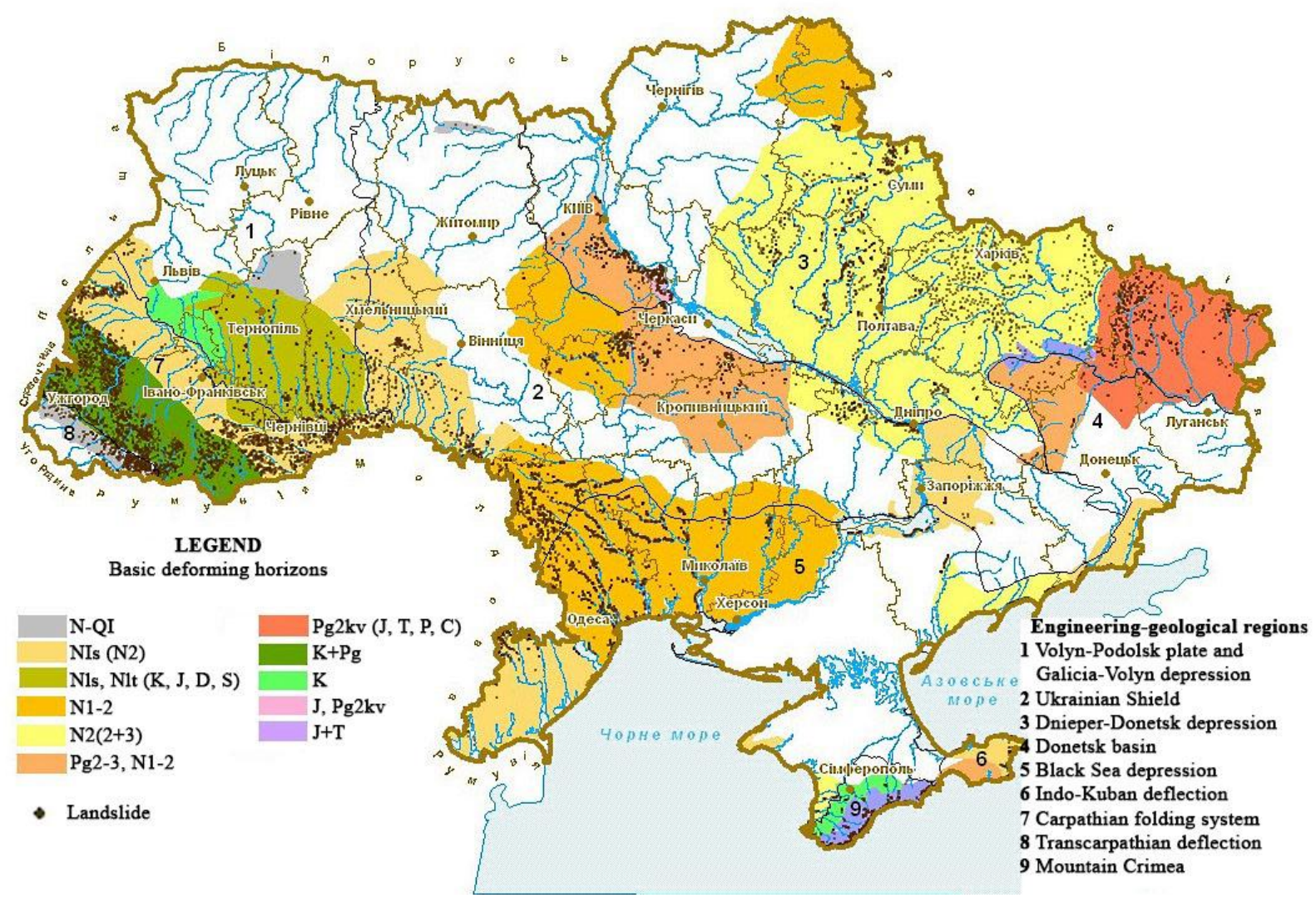

Fig. 1. The spread of landslides in Ukraine

The main factors of activation and formation of landslides within the region are shallow groundwater levels, lateral erosion, deep erosion of river valleys, high slope slope, rainfall intensity, etc. (Stakhov, 2006).

The territory of Skolivschyna refers to sites with significant engineering risk. This is facilitated by mountain relief with sharp altitudes and steep slopes. Even the slightest disturbance of slope integrity by any technogenic impact, accompanied by excavation at the bottom or middle of the slope, can cause catastrophic landslides. Landslides are also manifested in places of intensive deforestation. An interesting cognitive object is the ancient landslide on the bank of the Rybnik Maidansky River (Fig. 2a) (Modern denudation processes).

Other dangerous denudation phenomena include the likelihood of ascent of mudflows, which are most often formed in the river Opir. The mudflows of summer 1998 caused the destruction of roads, bridges, retaining walls and more. In late July - early August 2004, as a result of heavy rainfall in the National Nature Park (NNP) in the Skole Forestry, many mudflows came down (Fig. 2b).

In times of floods and heavy rainfall, landslides often intensify under the influence of mudflows, which can be very dangerous. There are several dangerous areas in the NNP where landslides and mudflows can form. In particular, the slopes of the Stryi River valley, which stretch from the village of Pidhorodtsi to the village of Verkhnye Sinyvidnoe, have noticeable ancient landslides, which are potentially dangerous for roads and residential buildings in heavy rainfall or rapid snowmelt. 
In the upper reaches of the Stryi River tributaries there are several old and stable landslides, which, under certain conditions, can take part in the formation of a solid component of mudflows and turn these tributaries into mudflows. There is a significant risk of dangerous landslides in the middle reaches of Kamianka River, and there are several distinctly stable landslides near the Korchanka Mountains that can supply a solid part of the mudflows.

In late July - early August 2004 under the influence of rain landslides damaged the road to the village of Kamyanka (Fig. 3a) and significantly changed the configuration of the waterfall on the Kamianka River (Fig. 3b). Roads along the banks of the river Butivlya and its tributaries were also destroyed. Often, modern denudation processes cause damage to communication lines, roads and recreation areas (Fig. 3c).

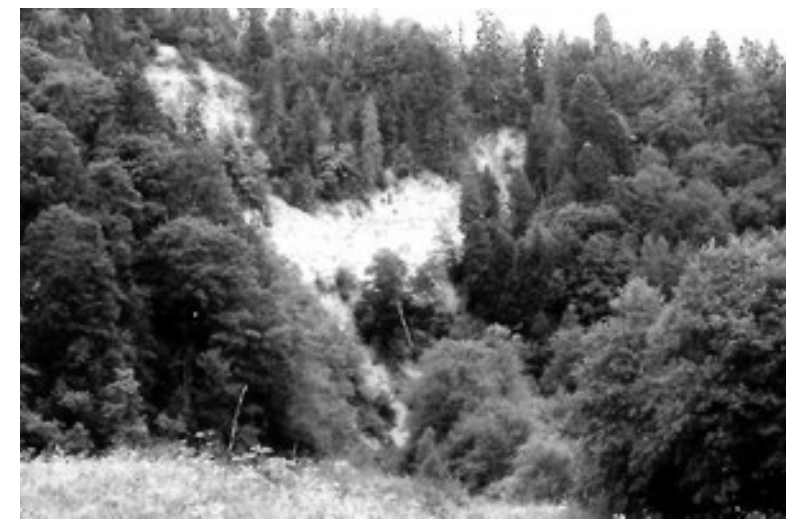

a

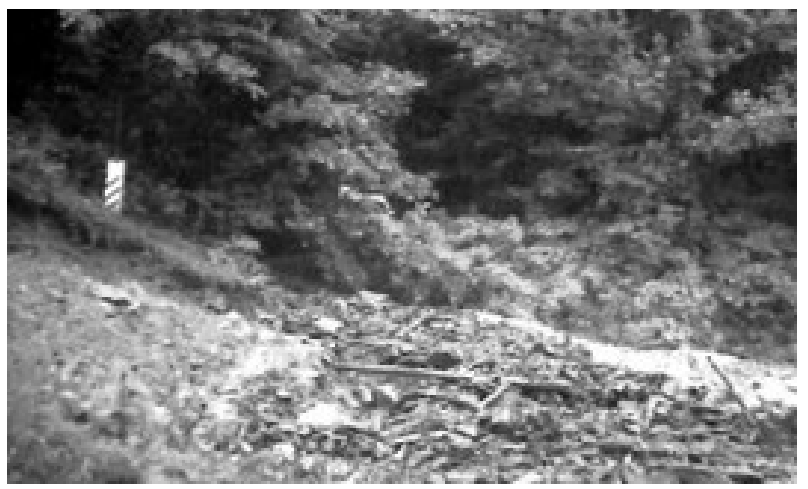

$b$

Fig.2. Landslide on the bank of the river Rybnik Maidanskyi (a) and the descent of the mudflow during the storm 30.VII.2004 (b)
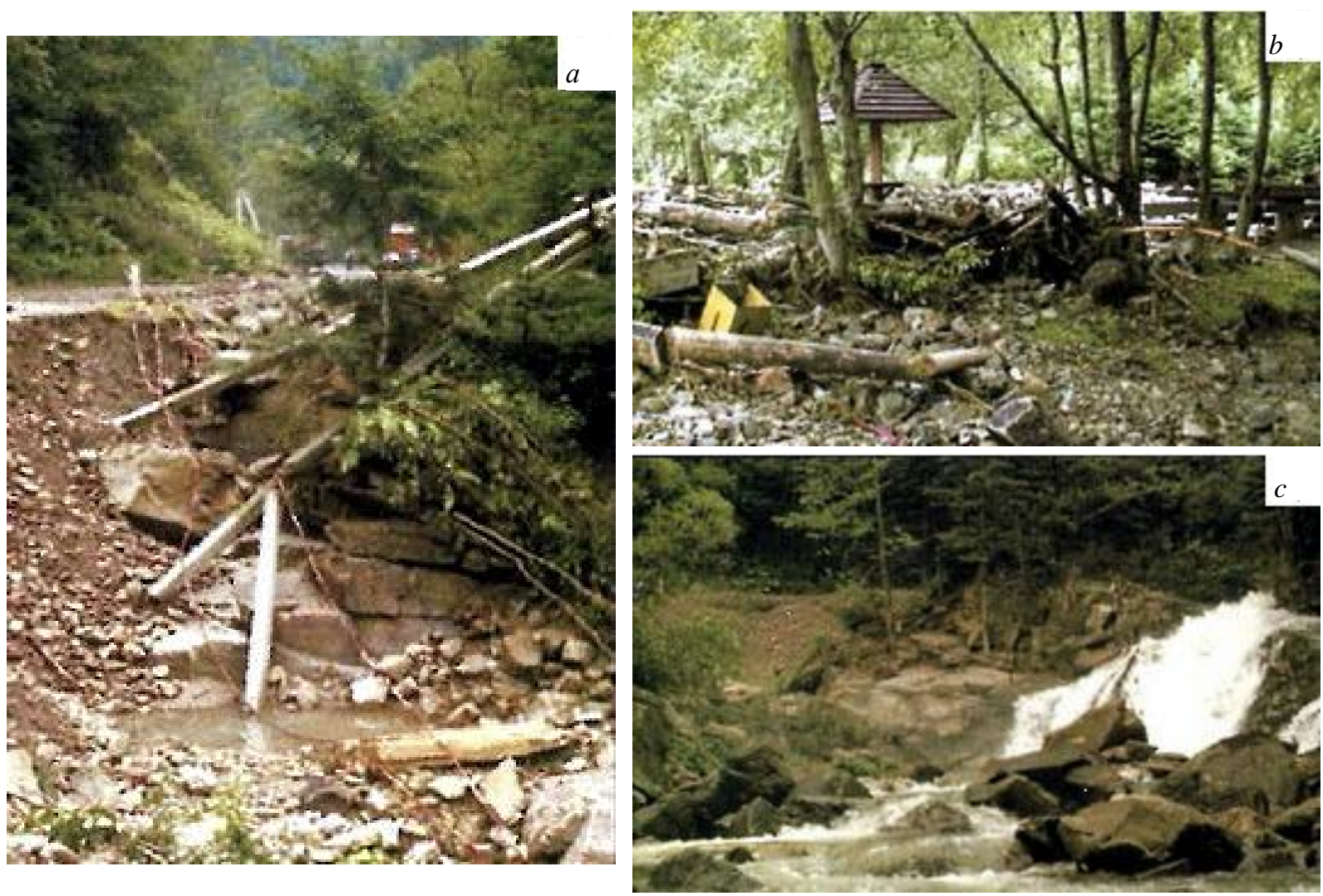

Fig. 3. Destruction due to heavy rains in 2004: a) landslide on the road to the village of Kamianka; b) damaged recreation area on Kamianka River; c) waterfall on Kamianka River after showers 
Improvement of quality and reliability of such important hydraulic structures as stream regulating half-dams, jet directional dams, water intakes, road bridges, floodplain and channel supports of power lines, etc. related to the improvement of the technical level of the objects of regulation of the beds of the mountain and foothill zone. 70-75\% of all road bridge crashes are associated with local erosion near bridge pillars and their foundations (Fig. 4). On critical sections of the banks of the Carpathian mountain rivers, most structures cannot withstand the pressure of the stream due to their intensive washing out with a breakdown of the blind area (Fig. 5).

Over the last five years, large floods occur on average twice a year, and according to long-term data they amount to 1.4-1.7 times a year. It is in case of catastrophic floods that significant changes in the kinematic structure of the flow are possible, which are caused by the dynamics of sediment and flow around them. Typically, such changes result in a sharp approach of the stream to the shore or structure, leading to a breakdown of the shoreline and to multiple deepening of the erosion (Khlapuk, 2014).
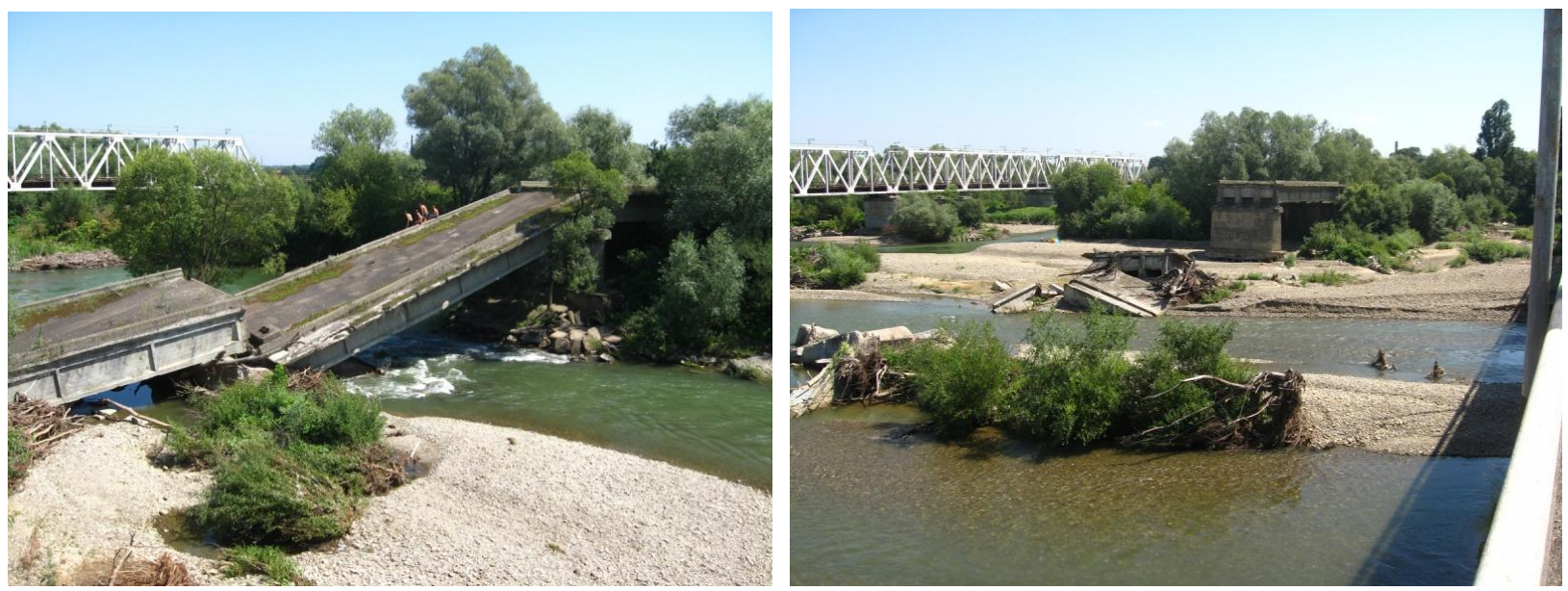

Fig. 4. The destroyed bridge, Stryi
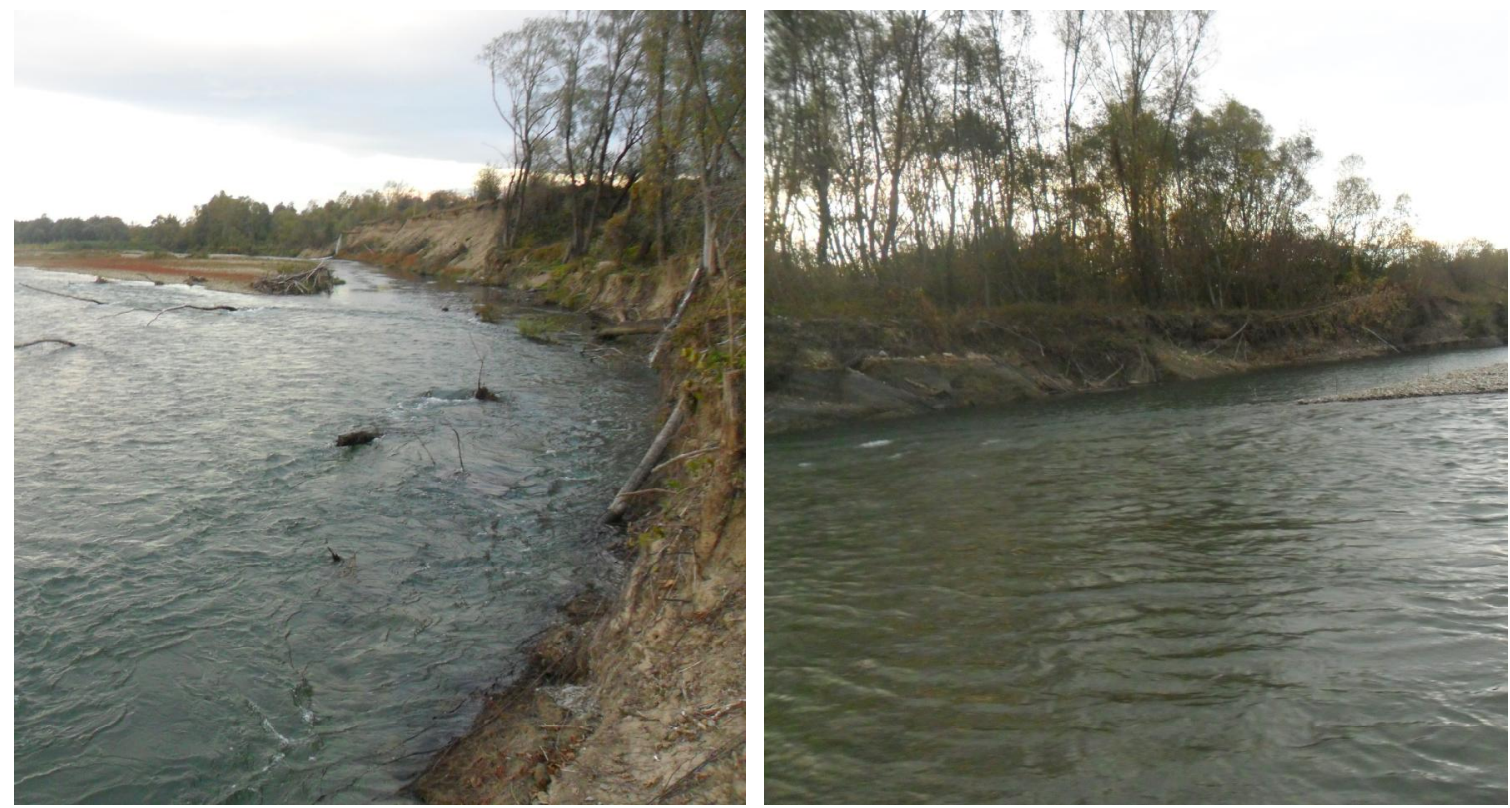

Fig. 5. Washing the coast on the river Stryi

Systematic hydrological observations make it possible to determine the main features of the Stryi River basin and regular changes in the status of the hydraulic system over time, which depend on climatic conditions (Gnativ, 2016). In some years, the spring flood is poorly expressed, but in summer and autumn 
there are high rainfall. Costs and volumes of runoff floods in the Stryi River basin in some years are much higher than the corresponding characteristics of the spring flood (Report on research work, 2013).

Periodic catastrophic floods $(1927,1955,1969,2008,2010)$ significantly influenced the state of engineering structures, coastal fortifications and erosion-accumulation processes. The idea of locating a floodwater reservoir near the village of Pidhorodtsi in the Skole district at the end of the twentieth century was not realized due to environmental concerns and economic problems (Hnativ, 2017).

\section{Conclusions}

The proliferation and activation of EGP, the study of the conditions of development and the renewal of their observations, are the first, urgent measures. The intensive management of economic activity in the regions over the last decades has seen a worsening of the geo-ecological situation with a steady tendency to develop EGP. The intensity of the manifestations of the latter significantly increases due to the influence of technogenic factors that cause disturbance of the natural balance of the environment.

Reducing the negative effects of EGP activation, predicting their development depend to a large extent on the timely identification of risks and the assessment and prediction of the extent of geological hazards.

Obtaining reliable data on the place of formation, factors of activation and development of dangerous exogenous processes can significantly influence the decision making to prevent and eliminate the negative consequences of activation of these processes.

Restoration of the system of constant monitoring of landslides, floods and washing of the banks and engineering structures on the rivers is urgently needed in the places of their intensive development in dangerous areas. In line with the requirements of the international monitoring network of the observation network, the points of information collection and processing require significant improvements.

\section{References}

Khlapuk M. M., Shtodro O. E., Shinkaruk L. A., Bezusyak O. V., Yasinskaya L. R. (2015). Generalization and use of scientific researches of the Department of Hydrotechnical Construction of NUVPP on Prevention of Harmful Effects of Waters on the Rivers of Ukraine. Bulletin of NUSPD. Issue 3 (71). Technical Sciences Series. Pp. 230-235. (in Ukrainian).

Information Yearbook on Activation of Hazardous Exogenous Geological Processes in the Territory of Ukraine According to EGP Monitoring (2018). Kyiv. State Service of Geology and Subsoil of Ukraine, State Scientific and Production Enterprise "State Information Geological Fund of Ukraine", 98 p. (in Ukrainian).

Khlapuk M. M., Shinkaruk L. A., Yasinskaya L. R. (2013).Investigation of the influence of bottom rapids on the structure of water flow in front of them in the foothill sections of rivers. Bulletin of NU Lviv Polytechnic. Construction theory and practice. Lviv, № 755. P. 449-456. (in Ukrainian).

Klimchuk L. N., Blinov P. V., Wieliczko V. F. and others (2008). Modern Engineering-Geological Conditions of Ukraine as a Component of Life Safety. Kyiv. EXPRESS. 205 p. (in Ukrainian).

Kolot E. (1988). A consolidated map of the conditions for the development of exogenous geological processes in the territory of the Ukrainian SSR at a scale of 1: 500 000. (in Russian).

Stakhov T. (2006). Report "Generalization of materials for the study of exogenous geological processes and engineering-geological study of the territory of Lviv and partially Transcarpathian regions in order to geologically justify landslides and geological support of the UIAS NS.

Modern denudation processes. Retrieved from http://skole.org.ua/denudacijni.html (in Ukrainian).

Khlapuk M. M., Shtodro O. E. (2014) Research of local erosion near river hydrotechnical structures. Hydropower of Ukraine, 2-3. P. 37-43. (in Ukrainian).

Gnativ R. M., Yakhno O. M., Gnativ I. R. (2016). Influence of quarrying on the change of longitudinal profiles in the mainstream of the river Stryi. Condact of modern science - 2016, November 30-december 7, 2016. Volume 16. Technical science, Mechanics. P. 8-10. 
Report on research work (2013). Carrying out a spatial analysis of changes in the water regime of surface water bodies in Ukraine due to climate change [Electronic resource]. 228 p. Retrieved from http://uhmi.org.ua/ project/rvndr/avr.pdf. (in Ukrainian).

Hnativ R. M., Petrynets V. Yu., Hnativ I. R. (2017). Development of measures in the river bed stream for protection of territories and settlements from floods and floods. Coll. materials of the first international Internet conference "Applied scientific and technical research", p. 149. (in Ukrainian).

В. В. Снітинський ${ }^{1}$, П. Р. Хірівський ${ }^{1}$, І. Р. Гнатів ${ }^{1}$, Р. М. Гнатів ${ }^{2}$

${ }^{1}$ Львівський національний аграрний університет,

${ }^{2}$ Національний університет “Львівська політехніка"

\title{
ЗСУВНІ ТА ЕРОЗІЙНІ ЯВИЩА НА ПЕРЕДГІРСЬКИХ ДІЛЯНКАХ РІЧОК КАРПАТСЬКОГО РЕГІОНУ
}

\author{
(C) Снітинський В. В., Хірівський П. Р., Гнатів I. Р., Гнатів Р. М., 2020
}

Різноманітність ландшафтних умов на території України зумовлена особливостями геоморфологічної будови, зонально-кліматичними, гідрогеологічними та сейсмічними факторами, що загалом визначає площі поширення екзогенних геологічних процесів (ЕГП). Більшість цих процесів, а саме зсуви, карстові утворення, підтоплення та ерозія територій, селеві потоки активізуються в природних умовах.

Необхідність оцінювання інженерно-геологічного стану територій із інтенсивним розвитком небезпечних гідрогеологічних процесів та впливу техногенних факторів, які визначають ступінь зміни та поширення процесів, є найважливішими для безпечного розвитку промисловості та сільського господарства. Незбалансована та безсистемна господарська діяльність спричинила негативні передумови для швидкого розвитку ЕГП, особливо в передгірських ділянках Карпатського регіону.

Протипаводковий захист населених пунктів, територій та об'єктів від затоплення є актуальною проблемою. Необхідне комплексне регулювання русел річок з врахуванням розвитку руслових процесів і прогнозуванням його можливих змін за впливу гідротехнічних та інженерних споруд. Сучасними методами протипаводкового захисту на річках Українських Карпат є регулювання русел за допомогою гідротехнічних регуляційних споруд.

Метою проведених досліджень $є$ аналіз факторів, що впливають на зсувні та ерозійні явища на передгірських ділянках Українських Карпат та вибір оптимального протипаводкового захисту населених територій від руйнування.

Отримання достовірних даних про місце формування, фактори активізації та розвитку небезпечних екзогенних процесів може істотно впливати на прийняття рішень для попередження $\mathrm{i}$ ліквідації негативних наслідків активізації цих процесів.

Відновлення системи постійних спостережень за зсувами, підтопленнями та підмиванням берегів та інженерних споруд на річках є вкрай необхідними у місцях їхнього інтенсивного розвитку на небезпечних ділянках. Відповідно до вимог міжнародного моніторингу довкілля мережі спостереження, пункти збирання інформації та їх опрацювання потребують значного покращення.

Ключові слова: екзогенні геологічні процеси, захист територій, повені, підтоплення, ерозія територій. 